\title{
Hemorheological consequences of hind limb ischemia-reperfusion differs in normal and gonadectomized male and female rats
}

\author{
${ }_{4}$ Norbert Nemeth*, Ferenc Kiss, Timea Hever, Endre Brath, Erika Sajtos, Istvan Furka \\ and Iren Miko \\ Department of Operative Techniques and Surgical Research, Institute of Surgery, \\ Medical and Health Science Center, University of Debrecen, Hungary
}

Received: 3 May 2011

Accepted: 26 June 2011

\begin{abstract}
It is known that hemorheological parameters show gender differences that might be altered by gonadectomy (GoE). Since micro-rheological parameters (erythrocyte deformability and aggregation) sensitively change during and after ischemiareperfusion (I/R), the question arises whether the hemorheological effects of $I / R$ may show gender differences and further changes might be expected when GoE and I/R are additive. Sprague-Dawley rats were divided into six groups: Control males and females, I/R males and females with 1-hour hind limb ischemia, GoE $+\mathrm{I} / / \mathrm{R}$ males and females when 3 months after bilateral gonadectomy the $\mathrm{I} / \mathrm{R}$ was induced. Before and just after ischemia, and on the 1st-3rd-5th-7th postoperative days blood samples were taken (lateral tail vein, $0.3-0.5 \mathrm{~mL}$ ) for analyzing hematological parameters, erythrocyte's deformability (slit-flow ektacytometer) and aggregation (light-transmission aggregometer). Leukocyte and platelet counts raised markedly in gonadectomized animals during the investigated days. Hemorheological changes of I/R showed gender differences: significant impairment of erythrocyte deformability was found on the 1 st-3rd postoperative days, expressed mostly in females. In gonadectomized females the postischemic deformability values were impaired. Erythrocyte aggregation index significantly raised by the 1st postoperative day, dominantly in males. It is suggested that gonadectomy may act as an additional rheological 'risk factor' related to blood micro-rheological parameters in ischemia-reperfusion.

Keywords: Ischemia-reperfusion, gonadectomy, gender differences, red blood cell aggregation, red blood cell deformability
\end{abstract}

\section{Introduction}

Numerous literature data support the fact that ischemia-reperfusion (I/R) and related complex pathophysiological processes may cause significant changes in blood rheological parameters, especially in red blood cell deformability and aggregation, in which changes the harmful and cascade-like complex effects of oxygen-derived free-radicals and leukocyte activation play pivotal roles $[4,8,18-22,34,35,38,51]$. These rheological changes may aggravate further the microcirculatory disorders $[4,19]$. The magnitude of the changes are depending on the ischemic duration, the type of the affected tissue and the temperature $[18,35,49]$. Hemorheological changes during and after I/R could be observed in the early reperfusion

\footnotetext{
${ }^{*}$ Corresponding author: Norbert Nemeth, MD, PhD., Department of Operative Techniques and Surgical Research, Medical and Health Science Centre, University of Debrecen, H-4032 Debrecen, Nagyerdei krt. 98., Hungary. Tel./Fax: +36 52 416 915; E-mail: nemeth@med.unideb.hu.
} 
period $[18,21,38]$ and later on, depending on the magnitude of the inflammation during the 1st-3rd postoperative days, reflecting the local and systemic changes as well [22, 34, 35, 38, 49].

The peripheral vascular diseases as well as microcirculatory changes caused by $I / R$ may show gender differences, underlying the importance of sex hormones as well as their concentration and the androgento-estrogen ratio $[16,17,24,28,37,48]$. Several in vivo experimental studies proved the protecting effect of estrogen in myocardial, cerebral and hind-limb ischemia-reperfusion injuries $[10,15,23,41,44,47$, 52]. The protective effect seems to be quite complex, including certain antioxidant properties, membrane stabilization effects, improvement of $\mathrm{NO}$ release, attenuating $\mathrm{Ca}^{2+}$ accumulation and preserving mitochondrial structure and function [27-30, 39, 47, 48, 52]. It was also demonstrated that estrogen may protect the red blood cells from damage and the presence of testosterone may render the erythrocytes more susceptible to oxidative stress after trauma-hemorrhagic shock [25]. However, the protective or non-protective effect of testosterone is still controversial [12]. Supposedly all of these in vivo effects are more complex than as it is in vitro.

Concerning the hemorheological gender differences in rats [32] and their changes after gonadectomy [33], it is supposed that the effect of I/R on erythrocyte deformability and aggregation may alter in female and males, that might differ further in gonadectomized animals. We aimed to investigate this question in a hind limb I/R follow-up study in rats.

\section{Materials and methods}

\subsection{Experimental animals and study design}

The experiments were approved and registered by the University of Debrecen Committee of Animal Research (permission Nr.: 37/2007, 17/2008), in accordance with the relevant Hungarian Animal Protection Act (Law XVIII/1998) and EU Directives (EEC 63/2010).

Twenty-five male and twenty-five female Sprague-Dawley rats (Janvier Co., France) were involved in the study. The animals were aged similarly to each other.

The healthy female animals were in pro-estrus phase, according to the investigation of vaginal smears with Giemsa dying.

\subsection{Operative techniques and sampling protocol}

The general anesthesia was provided by intraperitoneal administration of Thiopenthal ${ }^{\circledR}(60 \mathrm{mg} / \mathrm{kg})$. Six experimental groups were formed:

I. Control males $(n=8 ; 573.6 \pm 82 \mathrm{~g})$

II. Control females $(n=8 ; 326 \pm 11.8 \mathrm{~g})$ : besides of 2-hours anesthesia and blood samplings no further intervention was made.

III. Ischemia-reperfusion (I/R) males $(n=7 ; 586.2 \pm 54.1 \mathrm{~g})$ and IV. Ischemia-reperfusion (I/R) females $(n=7 ; 306.7 \pm 14.9 \mathrm{~g})$ : a tourniquet was placed around the left thigh closed to the level of the inguinal ligament. The completion of ischemia was checked by laser Doppler tissue flowmetry (LD-1, Experimetria Ltd., Hungary) placed on the paws. The ischemia was maintained for 1 hour.

V. Gonadectomy + ischemia-reperfusion $(\mathrm{GoE}+\mathrm{I} / \mathrm{R})$ males $(n=10 ; 508.8 \pm 33.2 \mathrm{~g})$ and VI. Gonadectomy + ischemia-reperfusion $(\mathrm{GoE}+\mathrm{I} / \mathrm{R})$ females $(n=10 ; 384.8 \pm 43.3 \mathrm{~g})$ : three months after bilateral orchidectomy or ovariectomy [33] the same protocol was completed as in I/R groups. 
After the ischemia and on the 1st postoperative day the animals received analgesics (Flunixin ${ }^{r}$ egd, $2.5 \mathrm{mg} / \mathrm{bwkg}$, s.c.). In the control animals the same dosage was used, in parallel.

By puncturing the lateral tail vein $0.3-0.5 \mathrm{~mL}$ blood was taken as base sample (anticoagulant: sodiumEDTA, $1.5 \mathrm{mg} / \mathrm{ml}$ ) from each animal. By the same way, 5 minutes after removing the tourniquet (postischemic sample), on the 1st, 2nd, 3rd and 7th postoperative days further blood samples were taken (0.3-0.5 mL per each), and in parallel from the Control animals. On the 7th day the blood sampling was completed under general anesthesia and the animals were sacrificed, ending the experiment.

\subsection{Laboratory investigations}

A Sysmex F-800 microcell counter (TOA Medical Electronics Co., Ltd., Japan) was used for determining general hematological parameters. Red blood cell count $\left(\mathrm{RBC}\left[\times 10^{6} / \mu \mathrm{l}\right]\right)$, hematocrit $(\mathrm{Hct}$ $[\%])$, hemoglobin ( $\mathrm{Hgb}[\mathrm{g} / \mathrm{dl}])$, mean corpuscular volume (MCV [fl]), mean corpuscular hemoglobin (MCH $[\mathrm{pg}]$ ), mean corpuscular hemoglobin concentration ( $\mathrm{MCHC}[\mathrm{g} / \mathrm{dl}])$, white blood cell count (WBC $\left.\left[\times 10^{3} / \mu \mathrm{l}\right]\right)$, monocyte-granulocyte and lymphocyte ratio (Mo-Gr\%, Lymph\%) and platelet count (Plt $\left.\left[\times 10^{3} / \mu 1\right]\right)$ were analyzed. A test requires approximately $70 \mu \mathrm{l}$ of blood.

Red blood cell deformability was measured by a Rheoscan-D200 ektacytometer (Sewon Meditech Inc., Korea) [42, 43]. For the measurements isotonic solution of polyvinylpyrrolidone ( $360 \mathrm{kDa}$, viscosity $=28.8 \mathrm{mPa} . \mathrm{s} ;$ osmolarity $=305 \mathrm{mOsm} / \mathrm{kg} ; \mathrm{pH}=7.36$ ) was prepared and $6 \mu \mathrm{l}$ of native blood was taken into $0.6 \mathrm{~mL}$ of the PVP solution, and gently mixed. The sample suspension was taken into Rheoscan disposable slit-flow kit, in which the fluid is moving by the force of the vacuum generated by the device, creating the required shear stress profile $(\sim 0.5-20 \mathrm{~Pa})$ for elongating the red blood cells. The red blood cells -while elongating and changing shape- alter the laser diffraction pattern. The elongation index (EI) at a constant shear stress (SS $[\mathrm{Pa}]$ ) is calculated from the length (L) and width (W) of the diffractogram: $\mathrm{EI}=(\mathrm{L}-\mathrm{W}) /(\mathrm{L}+\mathrm{W})$. EI increases with cell deformability [5]. For comparison EI values at 3 Pa were used and parameterization of individual curves Lineweaver-Burke analysis was completed, calculating the maximal elongation index $\left(\mathrm{EI}_{\max }\right)$ and the shear stress at half $\mathrm{EI}_{\max }\left(\mathrm{SS}_{1 / 2}[\mathrm{~Pa}]\right)$ [7].

Red blood cell aggregation was tested using light-transmission aggregometry (Myrenne MA-1 erythrocyte aggregometer, Myrenne $\mathrm{GmbH}$, Germany). This aggregometer determines $\mathrm{M}$ (at 0 shear rate) and M1 (at shear rate of $3 \mathrm{~s}^{-1}$ ) indices, reflecting the magnitude of red blood cell 'clumping' at the 5th or 10 th seconds of the aggregation process $[5,40]$. M and M1 indices increase with enhanced aggregation. The measurements require approximately $20 \mu \mathrm{l}$ of blood. The measurements were carried out within 1 hour after sampling $[5,31]$.

\subsection{Statistical analyses}

Data are presented as mean \pm standard deviation (S.D.). Based on the normality of data distribution, for inter-group comparison Student $t$-test or Mann-Whitney RS test, for intra-group comparison one-way ANOVA tests (Dunn's or Bonferroni's method) were used. A $p$ value less than 0.05 was considered as statistically significant.

For analyzing the magnitude of inter- and intra-group changes, standardized differences were calculated: dividing the mean difference of values (EI at $3 \mathrm{~Pa}, \mathrm{EI}_{\max }, \mathrm{SS}_{1 / 2}$ ) between the base (before operation) data and the postischemic or postoperative values at a given SS by the pooled standard deviation of the base and postichemic or postoperative data. The pooled standard deviation is calculated as the square root of the mean of squared standard deviations of the two groups being compared $[6,46]$. 


\section{Results}

\subsection{Hematological parameters}

In all I/R groups red blood cell count $\left(\mathrm{RBC}\left[\times 10^{6} / \mu \mathrm{l}\right]\right)$ and hematocrit $(\mathrm{Hct}[\%])$ slightly decreased by the 1st and 2nd postoperative day, and started to normalize from the 3rd day. There was no remarkable difference between groups. By the 7th day RBC and Hct values were similar to the normal, base data. Hemoglobin concentration, MCV and MCHC did not show important changes (data no shown).

The changes of white blood cell count $\left(\mathrm{WBC}\left[\times 10^{3} / \mu 1\right]\right)$ and platelet count $\left(\mathrm{Plt}\left[\times 10^{3} / \mu 1\right]\right)$ are shown in Table 1.

Compared to control animals, the ischemia-reperfusion resulted in a rise of WBC count by the 1st postoperative day with increasing monocyte-granulocyte ratio. In I/R males the increase was more expressed compared to females, showing significant gender difference on the 2 nd and 3 rd postoperative day $(p<0.001$ and $p=0.001$, respectively). Interestingly, in females the rise in WBC was diminished, presenting only a smaller, non-significant peak on the 3 rd postoperative day.

In $\mathrm{GoE}+\mathrm{I} / \mathrm{R}$ males and females the changes were of larger magnitude. On the 1 st day the increased WBC count of GoE $+\mathrm{I} / \mathrm{R}$ males was significant compared to the base values $(p<0.001)$ and versus control males $(p<0.001)$, I/R males $(p=0.002)$ and $\mathrm{GoE}+\mathrm{I} / \mathrm{R}$ females, too $(p<0.001)$. These differences were existing over the investigated postoperative period, showing slight decrease. On the 7 th day the elevated WBC count was still significant ( $p=0.007$ vs. base, $p=0.026$ vs. $\mathrm{I} / \mathrm{R}$ male, $p=0.01$ vs. $\mathrm{GoE}+\mathrm{I} / \mathrm{R}$ ). Additionally, in GoE $+\mathrm{I} / \mathrm{R}$ females the increased WBC count was significant on the $1 \mathrm{st}$ ( $p<0.001 \mathrm{vs}$. base, Control females and I/R females), the 2 nd ( $p<0.001$, all), the $3 \mathrm{rd}(p=0.007$ vs. base, $p=0.008$ vs. control females) and the 7 th postoperative days ( $p=0.003$ vs. base, $p<0.001$ vs. control and I/R females) (Table 1).

Compared to Control groups in Plt count of $\mathrm{I} / \mathrm{R}$ and $\mathrm{GoE}+\mathrm{I} / \mathrm{R}$ groups there was a decrease on the $1 \mathrm{st}-3 \mathrm{rd}$ postoperative days, followed by definitive increase on the 7th day, mostly expressed in GoE $+\mathrm{I} / \mathrm{R}$ females. The decrease started in the early postischemic period, that was remarkable in $\mathrm{I} / \mathrm{R}$ females ( $p=0.023 \mathrm{vs}$. base) and $\mathrm{GoE}+\mathrm{I} / \mathrm{R}$ females. On the 1st postoperative day the Plt count decrease was significant in all I/R groups (I/R males: $p=0.006, \mathrm{I} / \mathrm{R}$ females: $p=0.001, \mathrm{GoE}+\mathrm{I} / \mathrm{R}$ males: $p=0.005, \mathrm{GoE}+\mathrm{I} / \mathrm{R}$ females: $p=0.034)$, showing differences between the two $\mathrm{GoE}+\mathrm{I} / \mathrm{R}$ group, too $(p=0.011)$. On the 2 nd day further decrease was observed in all $\mathrm{I} / \mathrm{R}$ and $\mathrm{GoE}+\mathrm{I} / \mathrm{R}$ groups, then from the 3rd day slight increase started, reaching markedly elevated Plt count on the 7th day, mostly in $\mathrm{GoE}+\mathrm{I} / \mathrm{R}$ groups. In GoE $+\mathrm{I} / \mathrm{R}$ males the 7 th-day Plt count was significant versus its base $(p<0.001)$ and compared to Control males $(p=0.003)$; in $\mathrm{GoE}+\mathrm{I} / \mathrm{R}$ females the rise was significant compared to base values $(p<0.001)$ and versus 7 th-day values of I/R females, too $(p=0.004)$ (Table 1$)$.

\subsection{Red blood cell deformability}

Figure 1 shows the cumulated elongation index (EI) - shear stress (SS) curves in control, I/R and $\mathrm{GoE}+\mathrm{I} / \mathrm{R}$ male and female groups.

In Control male and female groups there were no remarkable changes during the investigated period (Fig. 1A, B). In I/R groups significant impairment of red blood cell deformability was observed on the 1st- 3rd postoperative days, expressed mostly by females (Fig. 1C, D). In GoE + I/R females the most decreased EI values were measured in postischemic samples (Fig. 1E, F). 
Table 1

Changes of white blood cell (WBC) count and platelet (Plt) count in Control, Ischemia-Reperfusion (I/R) and Gonadectomy+Ischemia-Reperfusion (GoE + I/R)

\begin{tabular}{|c|c|c|c|c|c|c|c|c|}
\hline \multirow[t]{2}{*}{ Variable } & \multirow[t]{2}{*}{ Group } & \multirow{2}{*}{ Gender } & \multirow[t]{2}{*}{ Base } & \multirow[t]{2}{*}{ Post-ischemic } & \multicolumn{4}{|c|}{ Postoperative days } \\
\hline & & & & & 1 st & 2nd & $3 \mathrm{rd}$ & 7 th \\
\hline \multirow{4}{*}[\times10^{3}/\mul]{} & Control & male & $7.9 \pm 2.07$ & & $5 \pm 1.52$ & $7.7 \pm 1.09$ & $8.5 \pm 0.84$ & $8.1 \pm 0.74$ \\
\hline & & female & $6.4 \pm 0.95$ & & $5.2 \pm 1.08$ & $5.9 \pm 0.89$ & $6.2 \pm 0.32$ & $5.8 \pm 1.25$ \\
\hline & $\mathrm{I} / \mathrm{R}$ & male & $7.6 \pm 2.12$ & $6.2 \pm 3.91$ & $9.1 \pm 3.36$ & $9.4 \pm 2.64^{\#+}$ & $8.7 \pm 5.14^{\#}$ & $6.5 \pm 5.09^{+}$ \\
\hline & & female & $5.6 \pm 1.55$ & $6.7 \pm 2.38^{\square}$ & $9.2 \pm 1.72^{*+\square}$ & $10 \pm 3.49^{*+\square}$ & $8.2 \pm 2.74^{*+}$ & $8.5 \pm 2.39^{*+\square}$ \\
\hline \multirow{3}{*}{$\begin{array}{l}\text { Plt } \\
{\left[\times 10^{3} / ! \mu 1\right]}\end{array}$} & & & & & & & & \\
\hline & Control & $\begin{array}{l}\text { male } \\
\text { female }\end{array}$ & $\begin{array}{l}776.9 \pm 104.6 \\
747.7+1401\end{array}$ & & $\begin{array}{l}707.9 \pm 140.4 \\
759.6 \pm 256.3\end{array}$ & $\begin{array}{c}754.8 \pm 64.5 \\
752.1 \pm 108.6\end{array}$ & $\begin{array}{l}721.6 \pm 74.1 \\
7851+143.6\end{array}$ & $\begin{array}{l}780.3 \pm 106.7 \\
773.3 \pm 195.5\end{array}$ \\
\hline & $\mathrm{I} / \mathrm{R}$ & male & $873.4 \pm 84.8$ & $802.9 \pm 286.8$ & $703.8 \pm 120.7^{*}$ & $638 \pm 122.1^{*+}$ & $740.1 \pm 88.42^{\text {*\# }}$ & $946.6 \pm 154.4^{+}$ \\
\hline
\end{tabular}



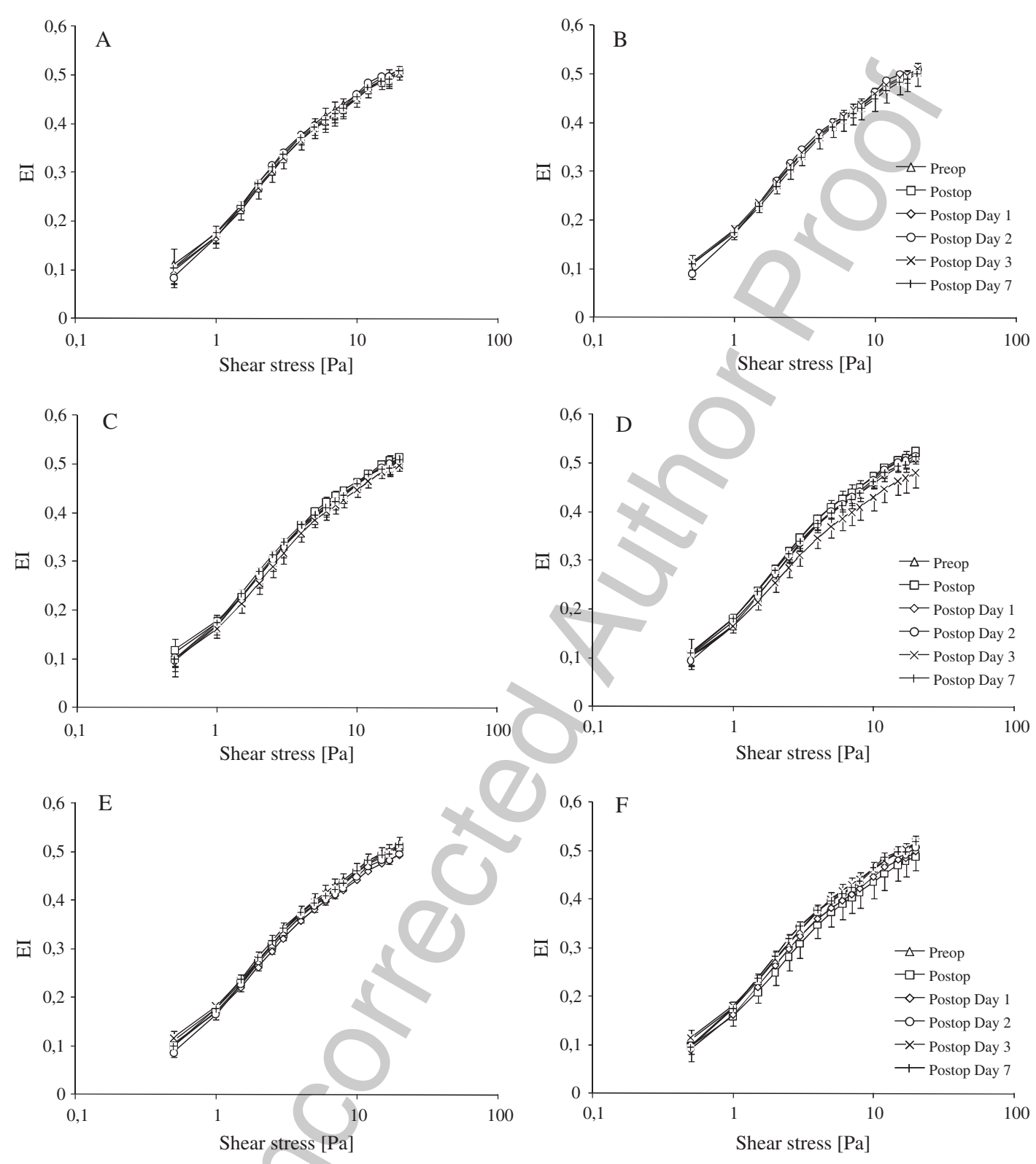

Fig. 1. Elongation index (EI) values of male and female Control (A, B), Ischemia-reperfusion (I/R) (C, D) and Gonadectomy + Ischemia-Reperfusion (GoEI/R) groups (E,F) in the function of shear stress (SS [Pa]) before (preop.) and after ischemia (postop.) an on the 1st, 3rd, 5th and 7th postoperative days. Means \pm S.D.

EI values at shear stress of $3 \mathrm{~Pa}$ remarkably decreased in $\mathrm{GoE}+\mathrm{I} / \mathrm{R}$ females just after ischemia that was significant compared to base values $(p=0.003)$, I/R females $(p<0.001)$ and versus $\mathrm{GoE}+\mathrm{I} / \mathrm{R}$ males $(p=0.016)$. On the 1 st postoperative day $\mathrm{I} / \mathrm{R}$ females as well as $\mathrm{GoE}+\mathrm{I} / \mathrm{R}$ males and females showed decrease EI values $(p<0.05)$. In $\mathrm{GoE}+\mathrm{I} / \mathrm{R}$ males the difference was significant compared to the $\mathrm{I} / \mathrm{R}$ male group, too $(p=0.025)$. The 3 rd day brought further impairment in $\mathrm{I} / \mathrm{R}$ males and females. In I/R males the 
decrease of EI was significant compared to $\mathrm{GoE}+\mathrm{I} / \mathrm{R}$ males $(p=0.013)$. In $\mathrm{I} / \mathrm{R}$ females the impairment was more obvious, being significant versus base values $(p<0.001)$ and Control females $(p<0.001)$. By the 7th day EI values seemed to be normalized (Fig. 2A).

The postischemic standardized difference was the highest in $\mathrm{GoE}+\mathrm{I} / \mathrm{R}$ females (1.09), while in the 1st3 rd postoperative days the highest values were expressed by $\mathrm{I} / \mathrm{R}$ females $(1.06,0.97$ and 2.28 , respectively) (Fig. 2B).
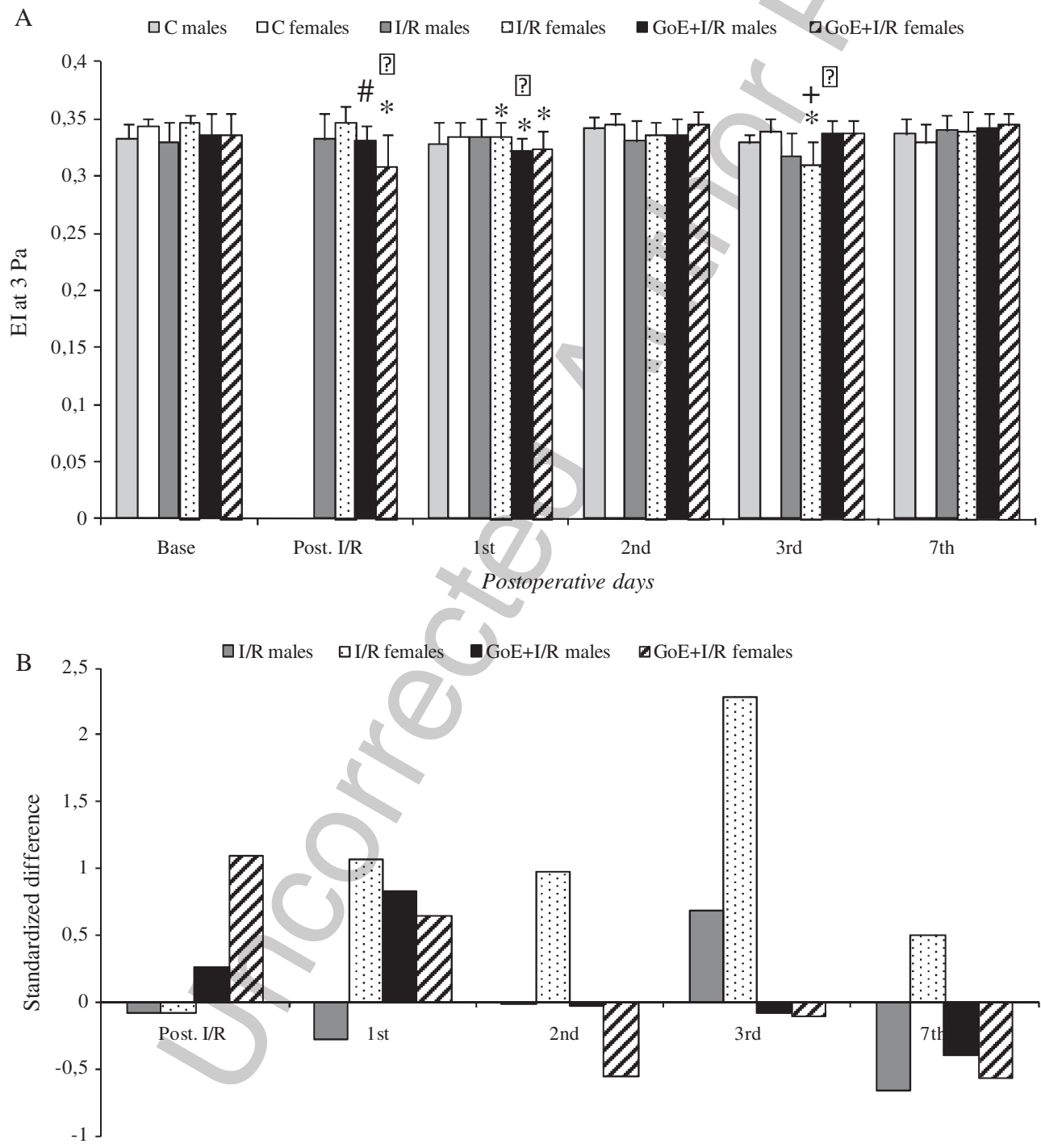

Postoperative days

Fig. 2. Elongation index values at shear stress of $3 \mathrm{~Pa}$ in Control (C), Ischemia-Reperfusion (I/R) and Gonadectomy + IschemiaReperfusion (GoE $+\mathrm{I} / \mathrm{R}$ ) male and female groups (A), and the standardized difference values (B) compared to base. means \pm S.D.

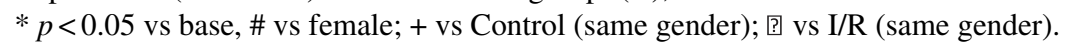


The calculated $\mathrm{EI}_{\max }$ reflected the above described changes. The lowest postichemic values were found in $\mathrm{GoE}+\mathrm{I} / \mathrm{R}$ females ( $p=0.011$ vs. base, $p<0.001$ vs. I/R females). The difference between $\mathrm{GoE}+\mathrm{I} / \mathrm{R}$ males and females did not reach the significant level $(p=0.068)$. On the 1 st postoperative day $\mathrm{I} / \mathrm{R}$ females and both $\mathrm{GoE}+\mathrm{I} / \mathrm{R}$ male and female groups showed the lowest $\mathrm{EI}_{\max }$ values, all being significant versus base ( $p<0.001, p=0.002$ and $p=0.032$, respectively). In $\mathrm{I} / \mathrm{R}$ females the difference was significant compared to Control females $(p=0.005)$. In $\mathrm{GoE}+\mathrm{I} / \mathrm{R}$ significant difference was found versus Control
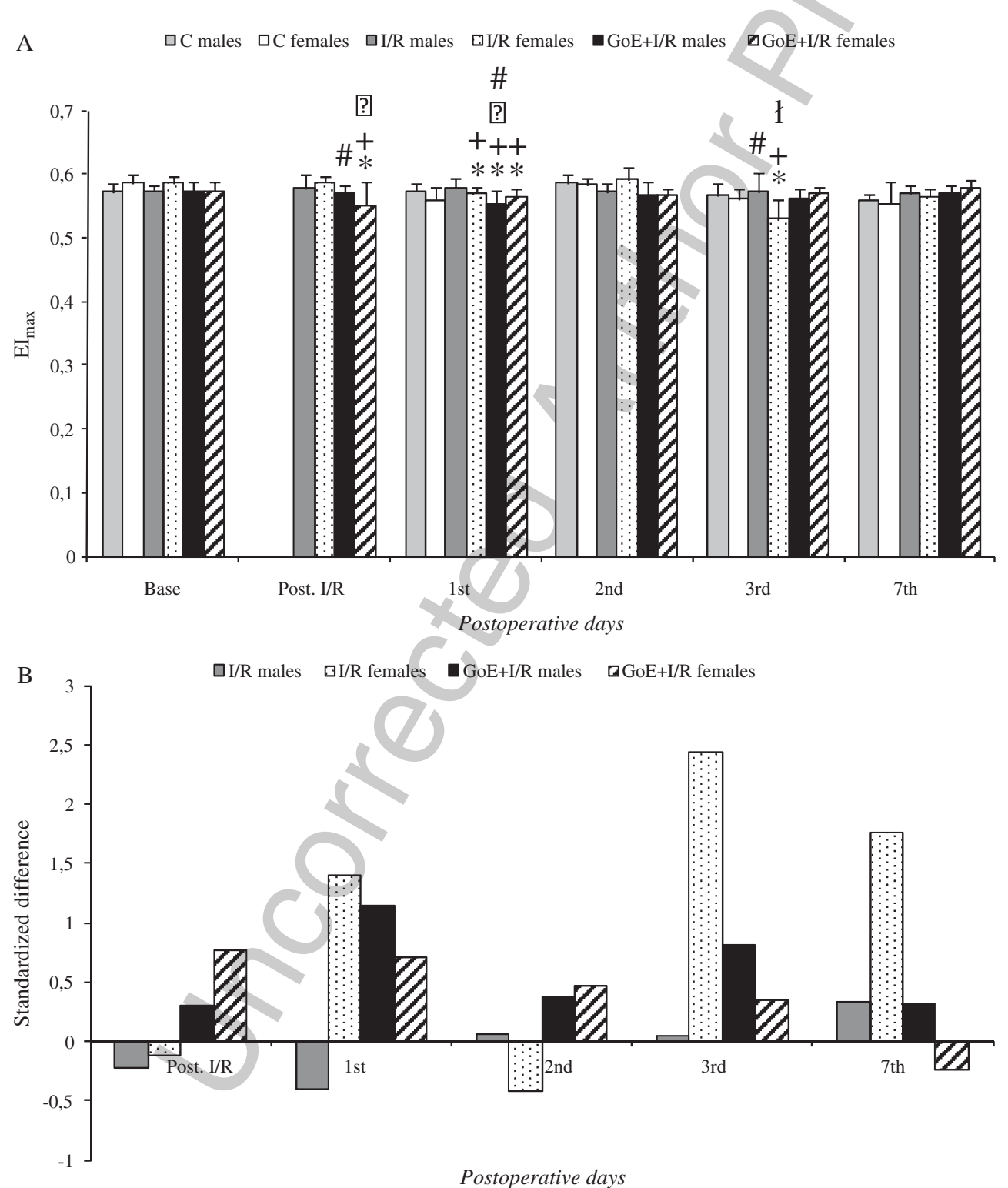

Fig. 3. Calculated maximal elongation index values $\left(\mathrm{EI}_{\max }\right)$ in Control $(\mathrm{C})$, Ischemia-Reperfusion (I/R) and Gonadectomy + Ischemia-Reperfusion $(\mathrm{GoE}+\mathrm{I} / \mathrm{R})$ male and female groups $(\mathrm{A})$, and the standardized difference values (B) compared to base. means \pm S.D. * $p<0.05$ vs base, \# vs female; + vs Control (same gender); ł vs GoE (same gender); ? vs I/R (same gender). 
females $(p<0.001)$ and $\mathrm{GoE}+\mathrm{I} / \mathrm{R}$ males $(p=0.044)$. GoE $+\mathrm{I} / \mathrm{R}$ males expressed lower $\mathrm{EI}_{\max }$ values compared to Control males $(p=0.007)$ and I/R males, too $(p=0.002)$. On the 3 rd postoperative day the lowest values were found in I/R females ( $p<0.001$ vs. base, $p=0.004$ vs. Control females, $p=0.003$ vs. $\mathrm{I} / \mathrm{R}$ males and $p<0.001$ compared to $\mathrm{GoE}+\mathrm{I} / \mathrm{R}$ females) (Fig $3 \mathrm{~A}$ ).

The standardized difference was the highest in $\mathrm{GoE}+\mathrm{I} / \mathrm{R}$ females in postischemic samples (0.77), and in I/R females on the 1st (1.39), the 3rd (2.43) and by the 7th (1.76) postoperative days (Fig. 3B).

Shear stress values at half $\mathrm{EI}_{\max }\left(\mathrm{SS}_{1 / 2}[\mathrm{~Pa}]\right)$ were increased in $\mathrm{GoE}+\mathrm{I} / \mathrm{R}$ postischemic $(p=0.006 \mathrm{vs}$. base) and 1st-day samples ( $p=0.021$ vs. base, $p=0.002$ vs. Control females), and in I/R females on

A
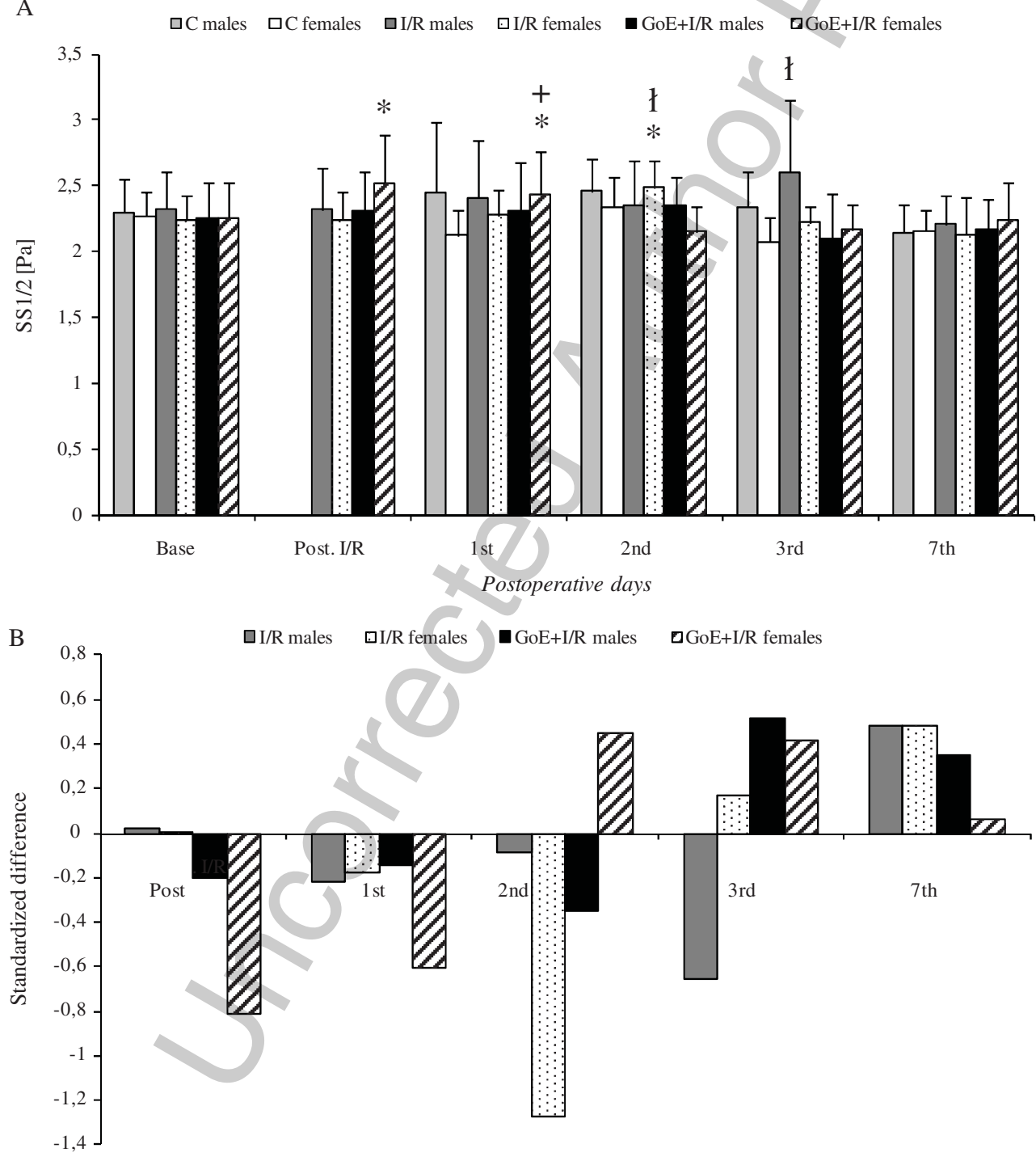

Postoperative days

Fig. 4. Calculated shear stress values at half maximal elongation $\left(\mathrm{SS}_{1 / 2}[\mathrm{~Pa}]\right)$ in Control (C), Ischemia-Reperfusion (I/R) and Gonadectomy + Ischemia-Reperfusion $(\mathrm{GoE}+\mathrm{I} / \mathrm{R})$ male and female groups (A), and the standardized difference values (B) compared to base. means \pm S.D. $* p<0.05$ vs base, \# vs female; + vs Control (same gender); $\nmid$ vs GoE (same gender). 
the 2 nd day ( $p=0.005$ vs. base, $p<0.001$ vs. GoE $+\mathrm{I} / \mathrm{R}$ females), furthermore, in $\mathrm{I} / \mathrm{R}$ males on the $3 \mathrm{rd}$ postoperative day ( $p=0.012 \mathrm{vs}$. GoE $+\mathrm{I} / \mathrm{R}$ males) (Fig. 4A).

The standardized difference was the largest in magnitude in postichemic samples of $\mathrm{GoE}+\mathrm{I} / \mathrm{R}$ females $(-0.8)$ and in I/R females on the 2nd day (-1.27) (Fig. 4B).

\subsection{Red blood cell aggregation}

Figure 5 shows changes of aggregation index values $M$ and $M 1$ at 5 - or 10 -second mode in $\mathrm{I} / \mathrm{R}$ and $\mathrm{GoE}+\mathrm{I} / \mathrm{R}$ male and female groups.

In postischemic samples of $\mathrm{GoE}+\mathrm{I} / \mathrm{R}$ females $\mathrm{M}(5 \mathrm{~s}$ and $10 \mathrm{~s})$ index values increased, being significant versus base (10 s: $p=0.019)$ and I/R females $(5 \mathrm{~s}: p<0.001)$.

On the 1st postoperative day all the index values remarkably increased, showing significance compared to base values (M $5 \mathrm{~s}$ : I/R males $p=0.003, \mathrm{I} / \mathrm{R}$ females $p=0.008$, GoE $+\mathrm{I} / \mathrm{R}$ males $p<0.001, \mathrm{GoE}+\mathrm{I} / \mathrm{R}$ females $p=0.031 ; \mathrm{M} 10 \mathrm{~s}$ : I/R males $p<0.001, \mathrm{I} / \mathrm{R}$ females $p=0.002$, $\mathrm{GoE}+\mathrm{I} / \mathrm{R}$ males $p<0.001$, $\mathrm{GoE}+\mathrm{I} / \mathrm{R}$ females $p=0.005 ; \mathrm{M} 15 \mathrm{~s}: \mathrm{I} / \mathrm{R}$ males $p<0.001, \mathrm{I} / \mathrm{R}$ females $p=0.012$, GoE $+\mathrm{I} / \mathrm{R}$ males $p<0.001, \mathrm{GoE}+\mathrm{I} / \mathrm{R}$ females $p=0.03 ; \mathrm{M} 110 \mathrm{~s}$ : I/R males $p<0.001, \mathrm{I} / \mathrm{R}$ females $p<0.001, \mathrm{GoE}+\mathrm{I} / \mathrm{R}$ males $p=0.03, \mathrm{GoE}+\mathrm{I} / \mathrm{R}$ females $p=0.016$ ).

On the 3rd postoperative day significant increase of aggregation was found interestingly in I/R male group when measuring M $10 \mathrm{~s}$ ( $p=0.015 \mathrm{vs}$. base and $p=0.015 \mathrm{vs}$. I/R females), M1 $5 \mathrm{~s}$ ( $p=0.003 \mathrm{vs.}$
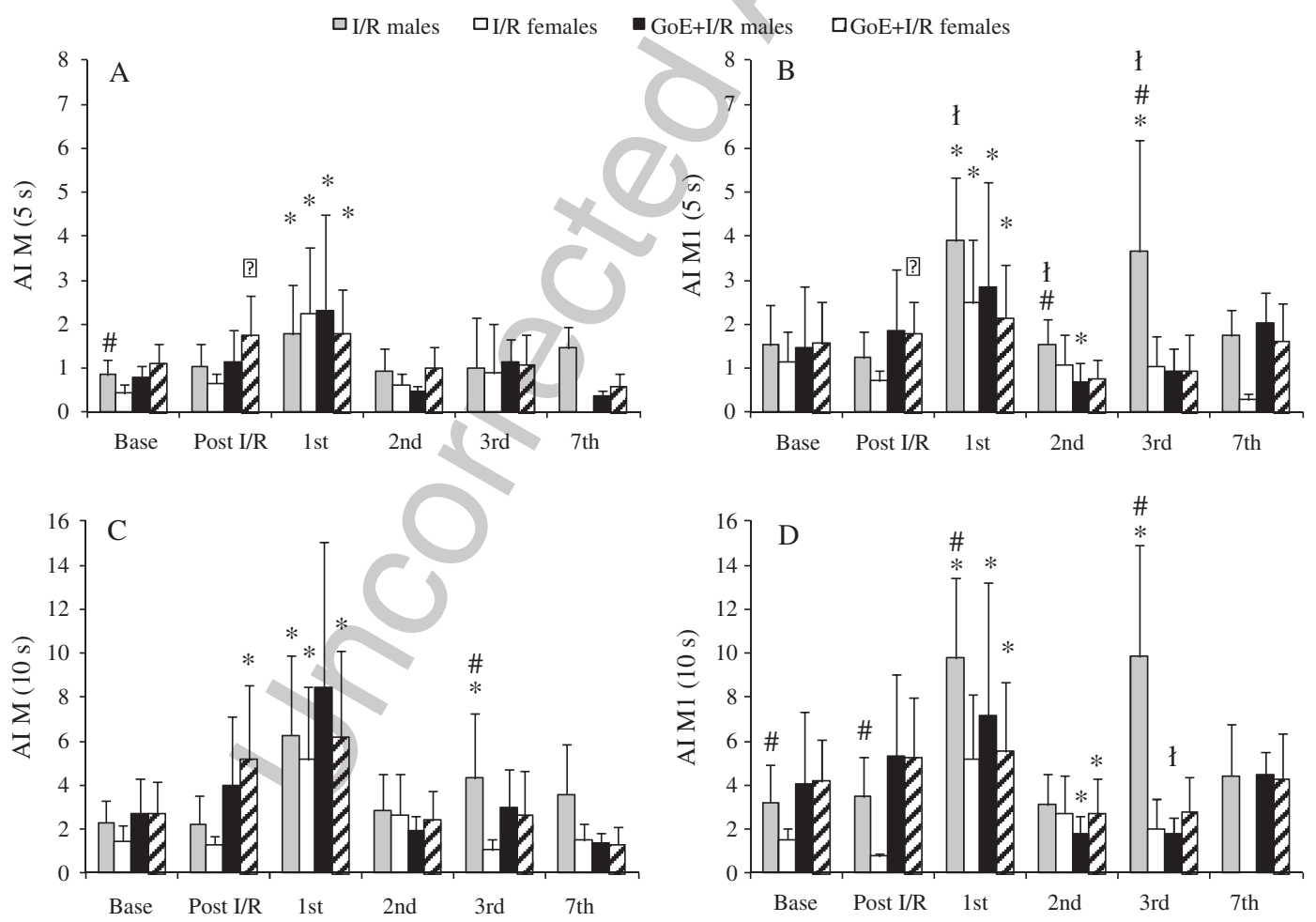

Fig. 5. Changes of aggregation index (AI) of M $5 \mathrm{~s}$ (A), M1 $5 \mathrm{~s}$ (B), M $10 \mathrm{~s}$ (C) and M1 $10 \mathrm{~s}$ (D) values in Control (C), Ischemia-Reperfusion (I/R) and Gonadectomy + Ischemia-Reperfusion ( $\mathrm{GoE}+\mathrm{I} / \mathrm{R})$ male and female groups. ${ }^{*} p<0.05$ vs base,

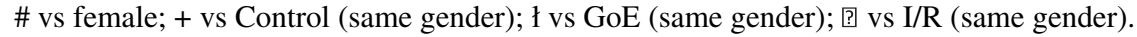


base, $p<0.001$ vs. I/R females and $p<0.001$ vs. $\mathrm{GoE}+\mathrm{I} / \mathrm{R}$ males) and $\mathrm{M} 110 \mathrm{~s}$ values ( $p<0.001$ vs. base, $\mathrm{I} / \mathrm{R}$ females and $\mathrm{GoE}+\mathrm{I} / \mathrm{R}$ males).

\section{Discussion}

It is known that red blood cell deformability is determined by cell volume, surface-to-volume ratio, morphology, cytoskeletal properties, inner viscosity as well as membrane viscosity [26]. The other important micro-rheological parameter, the red blood cell aggregation is influenced by both cellular (deformability, cell morphology, membrane glycocalyx structure) and plasmatic factors (fibrinogen concentration, micro-environmental conditions) [36]. These factors can be influenced by pathophysiological processes during $\mathrm{I} / \mathrm{R}$ at several points. Oxygen-derived free radicals are among the most important agents causing impaired cell deformability. The reactive free radicals cause direct and cascade-like harmful effects, including lipid peroxidation of the membrane, methemoglobin and Heinz-body formation - so increasing the inner viscosity of the cells as well as protein modification (e.g. by sulfhydryl cross-linking) - and consequent functional changes in transmembrane proteins, ion channels, structural proteins $[4,8,13$, 34, 45]. Changes in micro-environmental conditions (e.g. $\mathrm{pH}$, osmolarity, lactate concentration) as well as inflammatory processes, and as a part of acute phase reaction, the increased fibrinogen may cause enhanced red blood cell aggregation $[4,8,18,21,22]$.

Growing number of data underline the importance of hemorheological gender differences not only in the clinical investigations but also in the experimental medicine [32]. Furthermore, gonadectomy may additionally influence these micro-rheological gender differences, reflecting the influence of sex hormones, too [33]. The protective effect of estrogen has been demonstrated in numerous I/R studies including acute [47] and chronic hind limb [23], myocardial [10, 27, 30, 37, 52], brain [15, 41] and intestinal ischemia [48]. The effect of testosterone (protective or non-protective influence) is still controversial [12, 39, 48]. However, little is known related to micro-rheological changes.

In current study we aimed to investigate the effect of hind limb I/R on erythrocyte deformability and aggregation focusing on potential differences in female and males, that might differ further in gonadectomized rats.

The main findings were the followings: (1) I/R resulted in a rise of WBC count by the 1st postoperative day with increasing monocyte-granulocyte ratio. In I/R males the increase was more expressed compared to females, showing significant gender difference on the $2 \mathrm{nd}$ and $3 \mathrm{rd}$ postoperative day. In GoE $+\mathrm{I} / \mathrm{R}$ males and females the changes were of larger magnitude. (2) Compared to Control groups in Plt count of I/R and $\mathrm{GoE}+\mathrm{I} / \mathrm{R}$ groups there was a decrease on the $1 \mathrm{st}-3 \mathrm{rd}$ postoperative days, followed by definitive increase on the 7th day, mostly expressed in $\mathrm{GoE}+\mathrm{I} / \mathrm{R}$ females. (3) In I/R groups significant impairment of red blood cell deformability was observed on the 1 st-3rd postoperative days, expressed mostly by females. (4) In GoE + I/R females the most decreased EI values were measured in postischemic samples, together with significantly increased aggregation index values. (5) On the 1st postoperative day aggregation index values remarkably increased in all $\mathrm{I} / \mathrm{R}$ groups, while on the 3 rd day significant enhancement in aggregation was found only in $\mathrm{I} / \mathrm{R}$ male group.

In a rat model of hind limb I/R marked impairment of red blood cell deformability has been observed on the 1st and 2nd postoperative day, together with rise in leukocyte count and also an elevation of platelet count over the early postoperative days [34]. In that study by using microclips on femoral vessels 1-hour ischemia was induced. On the 1 st -7 th postoperative days small quantity of blood samples were taken for determining red blood cell deformability (by bulk filtrometry) and hematological parameters. The highly 
significant increase of relative cell transit time, reflecting impairment of red blood cell deformability, was seen on the 1st and 2nd postoperative days. These changes could be prevented by giving allopurinol, inhibitor of xanthine oxidase enzyme known to be the major source of superoxide during reperfusion [34].

According to these findings we have chosen the follow-up period of one week and the critical days to be investigated: 1 st $-3 \mathrm{rd}$ and 7 th postoperative days. The current findings nicely correlate with the previous results: the 1st and 3rd postoperative days were critical regarding the impairment of red blood cell micro-rheological properties.

The magnitude of changes in red blood cell deformability and red blood cell aggregation and their correlation to each other raise further questions. It is difficult to estimate the real relation between red blood cell deformability and red blood cell aggregation, and their changes. Interestingly, the females with lower bodyweight showed larger changes during the early postoperative days compared to males, while gonadectomized females expressed more obvious impairment in erythrocyte deformability just after ischemia.

The gonadectomized females had significantly augmented bodyweight compared to the same-age females of control and I/R groups. The obesity is known to affect numerous physiological parameters and pathways, causing abnormal insulin sensitivity, increased vasomotor tone, dyslipidemia, abnormalities in organs (e.g., liver, kidney), endothelial dysfunction and inflammation $[1,3,50]$. It has been reported that in obesity the bioavailability of nitric oxide $(\mathrm{NO})$ is reduced, due to peroxinitrite production by deliberating superoxide anion [3,9]. Furthermore obesity may affect guanylate cyclase pathways, formation of angiotensin II, expression of endothelin-1, and vasoconstrictor prostanoids [3, 50]. Obesity is also known to reduce the effect of ischemic preconditioning by enhanced mitochondrial oxidative stress, abnormal function of mito-K $\mathrm{K}_{\mathrm{ATP}}$ channels as well as due to the adverse effects of leptin, activating NAPDH oxidase $[2,14]$.

Since NO is known to improve [11], reactive oxygen-derived free radicals are known to impair red blood cell deformability [4, 8, 34], it is supposed that the existing obesity in ovariectomized females could affect the magnitude of red blood cell deformability changes in the early reperfusion period.

\section{Conclusions}

Hemorheological effects of 1-hour hind limb ischemia and the following reperfusion showed gender differences in rats, reflecting significant impairment of red blood cell deformability on the 1st-3rd postoperative days, mostly expressed in females. In gonadectomized females the postischemic elongation index values were the lowest with enhanced red blood cell aggregation. Aggregation index values significantly raised by the 1 st postoperative day after I/R, dominantly in males. White blood cell count and platelet count raised more markedly in gonadectomized animals during the early postoperative days.

According to the findings, further question arises whether the gonadectomy may act as an additional rheological 'risk factor' related to blood micro-rheological parameters in ischemia-reperfusion. This issue needs further study to clarifying the findings.

\section{Acknowledgments}

Authors are grateful to the technical and laboratory staff of the Department of Operative Techniques and Surgical Research at University of Debrecen. Grants: The Hungarian Research Fund OTKA F-68323 and OTKA K-67779; Janos Bolyai Research Scholarship of the Hungarian Academy of Sciences. 
The authors comply with the Ethical Guidelines for Publication in Clinical Hemorheology and Microcirculation as published on the IOS Press website and in Volume 44, 2010, pp. 1-2 of this journal.

\section{References}

[1] B.A. Al-Tahami, Y.T. Bee, A.A. Ismail and A.H. Rasool, Impaired microvascular endothelial function in relatively young obese humans is associated with altered metabolic and inflammatory markers, Clin Hemorheol Microcirc 47 (2011), 87-97.

[2] P. Balakumar, H. Singh, M. Singh and M.B. Anand-Srivastava, The impairment of preconditioning-mediated cardioprotection in pathological conditions, Pharmacol Res 60 (2009), 18-23.

[3] M. Barton, Obesity and aging: determinants of endothelial cell dysfunction and atherosclerosis, Pflugers Arch - Eur, $J$ Physiol 460 (2010), 825-837.

[4] O.K. Baskurt, Mechanisms of blood rheology alterations, in: Handbook of Hemorheology and Hemodynamics, O.K. Baskurt, M.R. Hardeman, M.W. Rampling and H.J. Meiselman eds., IOS Press, Amsterdam, The Netherlands, 2007, pp. 170-190.

[5] O.K. Baskurt, M. Boynard, G.C. Cokelet, P. Connes, B.M. Cooke, S. Forconi, M.R. Hardeman, F. Jung, F. Liao, H.J. Meiselman, G. Nash, N. Nemeth, B. Neu, B. Sandhagen, S. Shin, G. Thurston and J.L. Wautier, International expert panel for standardization of hemorheological methods, new guidelines for hemorheological laboratory techniques, Clin Hemorheol Microcirc 42 (2009), 75-97.

[6] O.K. Baskurt, M.R. Hardeman, M. Uyuklu, P. Ulker, M. Cengiz, N. Nemeth, S. Shin, T. Alexy and H.J. Meiselman, Comparison of three commercially available ektacytometers with different shearing geometries, Biorheology 46 (2009), 251-264.

[7] O.K. Baskurt and H.J. Meiselman, Analyzing shear stress-elongation index curves: Comparison of two approaches to simplify data presentation, Clin Hemorheol Microcirc 31 (2004), 23-30.

[8] O.K. Baskurt, A. Temiz and H.J. Meiselman, Effect of superoxide anions on red blood cell rheologic properties, Free Rad Biol Med 24 (1998), 102-110.

[9] S.B. Bender, E.K. Herrick, N.D. Lott and R.E. Klabunde, Diet-induced obesity and diabetes reduce coronary response to nitric oxide due to reduced bioavailability in isolated mouse hearts, Diab Obes Metab 9 (2007), 688-696.

[10] E.A. Booth and B.R. Lucchesi, Estrogen-mediated protection in myocardial ischemia-reperfusion injury, Cardiovasc Toxicol 8 (2008), 101-113.

[11] M. Bor-Kucukatay, R.B. Wenby, H.J. Meiselman and O.K. Baskurt, Effects of nitric oxide on red blood cell deformability, Am J Physiol Herat Circ Physiol 284 (2003), H1577-H1584.

[12] S.E. Borst, J.C. Quindry, J.F. Yarrow, C.F. Conover and S.K. Powers, Testosterone administration induces protection against global myocardial ischemia, Horm Metab Res 42 (2010), 122-129.

[13] S. de Oliveira and C. Saldanha, An overview about erythrocyte membrane, Clin Hemorheol Microcirc 44 (2010), 63-74.

[14] F. Dong, X. Zhang and J. Ren, Leptin regulates cardiomyocyte contractile function through endothelin-1 receptor-NADPH oxidase pathway, Hypertension 47 (2006), 222-229.

[15] D.B. Dubal, M.L. Kashon, L.C. Pettigrew, J.M. Ren, S.P. Finklestein, S.W. Rau and P.M. Wise, Estradiol protects against ischemic injury, J Cereb Blood Flow Metab 18 (1998), 1253-1258.

[16] J. Feinglass, M.M. McDermott, M. Foroohar and W.H. Pearce, Gender differences in interventional management of peripheral vascular disease: evidence from a blood flow laboratory population, Ann Vasc Surg 8 (1994), 343-349.

[17] F.G. Fowkes, J.P. Pell, P.T. Donnan, E. Housley, G.D.O. Lowe, R.A. Riemersma and R.J. Prescott, Sex differences in susceptibility to etiologic factors for peripheral arteriosclerosis, Importance of plasma fibrinogen and blood viscosity, Arterioscler Thromb 14 (1994), 862-868.

[18] A. Furka, N. Nemeth, A. Gulyas, E. Brath, K. Peto, E.I. Takacs, I. Furka, P. Sapy and I. Miko, Hemorheological changes caused by intermittent Pringle (Baron) maneuver in experimental beagle canine model, Clin. Hemorheol Microcirc 40 (2008), 177-189.

[19] T. Gori, M. Lisi and S. Forconi, Ischemia and reperfusion: the endothelial perspective. A radical review, Clin Hemorheol Microcirc 35 (2006), 31-34

[20] A. Jabs, F. Fasola, S. Muxel, T. Münzel and T. Gori, Ischemic and non-ischemic preconditioning: Endothelium-focused translation into clinical practice, Clin Hemorheol Microcirc 45 (2010), 185-191. 
[21] E. Kayar, F. Mat, H.J. Meiselman and O.K. Baskurt, Red blood cell rheological alterations in a rat model of ischemiareperfusion injury, Biorheology 38 (2001), 405-414.

[22] R. Koppensteiner and R., Blood rheology in emergency medicine, Semin Thromb Hemost 22 (1996), 89-91.

[23] Z.S. Kyriakidesa, P. Petinakisa, L. Kaklamanisa, E. Sbarounia, P. Karayannakos, D. Iliopoulos, I. Dontas and D.T. Kremastinos, Intramuscular administration of estrogen may promote angiogenesis and perfusion in a rabbit model of chronic limb ischemia, Cardiovasc Res 49 (2001), 626-633.

[24] K.K. Lam, C.T. Hu, T.Y. Ou, M.H. Yen and H.I. Chen, Effects of oestrogen replacement on steady and pulsatile haemodynamics in ovariectomized rats, Br J Pharmacol 136 (2002), 811-818.

[25] G.W. Machiedo, S. Zaets, T. Berezina, D.Z. Xu, Z. Spolarics and E.A. Deitch, Red blood cell damage after traumahemorrhage is modulated by gender, J Trauma 56 (2004), 837-844.

[26] H.J. Meiselman, Morphological determinants of red blood cell deformability, Scand J Clin Lab Invest 156 (41 Suppl) (1981), 27-34.

[27] D.R. Meldrum, M. Wang, B.M. Tsai, A. Kher, J.M. Pitcher, J.W. Brown and K.K. Meldrum, Intracellular signaling mechanisms of sex hormones in acute myocardial inflammation and injury, Front. Biosci 10 (2005), 1835-1867.

[28] M.E. Mendelsohn and R.H. Karas, Molecular and cellular basis of cardiovascular gender differences, Science 308 (2005), $1583-1587$.

[29] M.E. Mendelsohn, Estrogen actions in the cardiovascular system, Climacteric 12 (Suppl 1) (2009), 18-21.

[30] E. Murphy and C. Steenbergen, Gender-based differences in mechanisms of protection in myocardial ischemia-reperfusion injury, Cardiovasc Res 75 (2007), 478-486.

[31] N. Nemeth, O.K. Baskurt, H.J. Meiselman, F. Kiss, M. Uyuklu, T. Hever, E. Sajtos, P. Kenyeres, K. Toth, I. Furka and I. Miko, Storage of laboratory animal blood samples causes hemorheological alterations: Inter-species differences and the effects of duration and temperature, Korea-Aust Rheol J 21 (2009), 127-133.

[32] N. Nemeth, F. Kiss, I. Furka and I. Miko, Gender differences of blood rheological parameters in laboratory animals, Clin Hemorheol Microcirc 45 (2010), 263-272.

[33] N. Nemeth, F. Kiss, Zs. Magyar, K. Miszti-Blasius and I. Furka, Following-up hemorheological consequences of gonadectomy in male and female rats, Clin Hemorheol Microcirc - submitted.

[34] N. Nemeth, T. Lesznyak, M. Szokoly, I. Furka and I. Miko, Allopurinol prevents erythrocyte deformability impairing but not the hematological alterations after limb ischemia-reperfusion in rats, J Invest Surg 19 (2006), 47-56.

[35] N. Nemeth, M. Szokoly, G. Acs, E. Brath, T. Lesznyak, I. Furka and I. Miko, Systemic and regional hemorheological consequences of warm and cold hind limb ischemia-reperfusion in a canine model, Clin Hemorheol Microcirc 30 (2004), $133-145$.

[36] B. Neu and H.J. Meiselman, Red blood cell aggregation, in: Handbook of Hemorheology and Hemodynamics, O.K. Baskurt, M.R. Hardeman, M.W. Rampling and H.J. Meiselman eds., IOS Press, Amsterdam, The Netherlands, 2007, pp. 114-136.

[37] B. Ostadal, I. Netuka, J. Maly, J. Besik and I. Ostadalova, Gender differences in cardiac ischemic injury and protectionexperimental aspects, Exp Biol Med (Maywood) 234 (2009), 1011-1019.

[38] K. Peto, N. Nemeth, E. Brath, E.I. Takacs, O.K. Baskurt, H.J. Meiselman, I. Furka and I. Miko, The effects of renal ischemia-reperfusion on hemorheological factors: preventive role of allopurinol, Clin Hemorheol Microcirc 37 (2007), 347-358.

[39] E.H. Schmidt, W. Holzgreve and F.K. Beller, Effects of castration, exogenous testosterone and estrogen on endotoxin response in male rats, Eur J Obstet Gynecol Reprod Biol 25 (1987), 347-353.

[40] H. Schmid-Schönbein, H. Malotta and F. Striesow, Erythrocyte aggregation: causes, consequences and methods for assessment, Tijdschr NVKC 15 (1990), 88-97.

[41] J. Shi, J.D. Bui, S.H. Yang, Z. He, T.H. Lucas, D.L. Buckley, S.J. Blackband, M.A. King, A.L. Day and J.W. Simpkins, Estrogens decrease reperfusion-associated cortical ischemic damage. An MRI analysis in a transient focal ischemia model, Stroke 32 (2001), 987-992.

[42] S. Shin, Y. Ku, M.S. Park and J.S. Suh, Slit-flow ektacytometry: laser diffraction in a slit rheometer, Cytometry Part B (Clinical Cytometry) 65 (2005), 6-13.

[43] M.J. Simmonds, O.K. Baskurt, H.J. Meiselman and S.M. Marshall-Gradisnik, A comparison of capillary and venous blood sampling methods for the use in haemorheology studies, Clin Hemorheol Microcirc 47 (2011), 111-119.

[44] X. Song, G. Li, J. Vaagez and G. Valen, Effects of sex, gonadectomy, and oestrogen substitution on ischaemic preconditioning and ischaemia-reperfusion injury in mice, Acta Physiol Scand 177 (2003), 459-466.

[45] M.I. Spengler, M. Rasia, S. Palma and D. Allemandi, Effects of ascorbate fatty ester derivatives on erythrocyte membrane lipoperoxidation, Clin Hemorheol Microcirc 47 (2011), 163-168. 
[46] J. Stuart, P.C.W. Stone, G. Freyburger, M.R. Boisseau and D.G. Altman, Instrument precision and biological variability determine the number of patients required for rheological studies, Clin Hemorheol 9 (1989), 181-197.

[47] N. Stupka and P.M. Tiidus, Effects of ovariectomy and estrogen on ischemia-reperfusion injury in hindlimbs of female rats, J Appl Physiol 91 (2001), 1828-1835.

[48] A. Szabo, B. Vollmar, M. Boros and M.D. Menger, Gender differences in ischemia-reperfusion-induced microcirculatory and epithelial dysfunction in the small intestine, Life Sci 78 (2006), 3058-3065.

[49] M. Szokoly, N. Nemeth, I. Furka and I. Miko, Hematological and hemostaseological alterations after warm and cold limb ischemia-reperfusion in a canine model, Acta Cir Bras 24 (2009), 338-346.

[50] P.M. Vanhouette, H. Shimokawa, E.H. Tang and M.Feletou, Endothelial dysfunction and vascular disease, Acta Physiol (Oxf) 196 (2009), 193-222.

[51] T. Waldow, W. Witt and K. Matschke, Inhibition of glycogen synthase kinase- $3 \beta$ prevents activation of focal adhesion kinase after ischemia-reperfusion of the rat lung, Clin Hemorheol Microcirc 46 (2010), 169-181.

[52] P. Zhai, T.E. Eurell, R. Cotthaus, E.H. Jeffery, J.M. Bahr and D.R. Gross, Effect of estrogen on global myocardial ischemiareperfusion injury in female rats, Am J Physiol Heart Circ Physiol 279 (2000), H2766-H2775. 